\title{
CHANGE - SOCIAL AND PERSONAL: THOMAS AND ZNANIECKI'S THE POLISH PEASANT FOR THE STUDY OF PRESENT-DAY CHANGE IN GLOBAL HIGHER EDUCATION
}

The sociological study of change - social and personal - owes much of its origin to W.I. Thomas and Florian Znaniecki's pioneering work The Polish Peasant in Europe and America. They offered an approach to the study of society, indicative of what others would recognize as the Chicago School of Sociology, that located people in their ecologically situated environments. An interactionist perspective informed their theoretic orientation: self and society, individual and institution are thought to be created reciprocally by an interplay of macro and micro forces.

The present work represents an extrapolation of W.I. Thomas and Florian Znaniecki's study on behalf of the development of sociological theory. The subject consists of careers and institutions in higher education. The curriculum vitae ('the course of a life') serves as the human document by which to investigate both social and personal change. Academic careers are studied by virtue of their objective and subjective dimensions.

Objectively, the institution of education is revealed through the shifting expectations that govern work in academia. The expectations may be seen to shift in specific historical times (indicated by the cohort in which academics earned their Ph.D.s) and in specific socially bound places (indicated by the type of university in which academics work). Major social change in education is likely to spell personal change for the way in which people subjectively experience the contemporary academic career.

While the data for the present article come from U.S.-based academics, parallel transformational changes are observable globally. The global change discussed in the present work centres on the diffusion and institutionalization of the research role. The sources and consequences of this change are problematic. Akin to Thomas and Znaniecki's larger analytic aims, patterns of change are used inductively to formulate theory: I close the paper by postulating a theory of the emerging way in which knowledge is produced in universities throughout the world. 


\section{THE CURRICULUM VITAE AS LIFE DOCUMENT}

The discussion that follows is motivated by the following question: What can a CV tell us about social change? There is some variation in the composition of CVs, usually in terms of length, across national systems of higher education. But there is strikingly more similarity than there is difference, a manifestation of what Meyer and his colleagues understand as the global institutionalism of education. ${ }^{1}$

For present purposes, I work with the American academic CV model which, in contrast to the systems of the United Kingdom, Ireland, and some other countries, is a comprehensive document that contains detailed listings of publications, formal education, positions held and corresponding institutional affiliations, grants, and other achievements, and also sometimes courses taught, professional service activities, professional memberships, theses and dissertations directed, and talks given.

The curriculum vitae is at once a 'course of a life' and the institutional embodiment of a life course. Individuals 'create' CVs, but institutions provide scripts for them. Their rough similarity across systems of higher education bespeaks scripting. The self and the life course are themselves institutionalized. 'In the modern systems, people work out selves with a great deal of institutional support. The legal, economic, political, and religious rules prescribing and legitimating personhood have standing. As actors form their own subjective personhood, they are perhaps as much affected by the institutionalized recipes as by any untutored "experiences".'2

CVs trace individual activities, but they are a manifestation of institutional norms governing careers. This a key theoretic point that accounts for the findings and discussion herein. Change in CVs reflect change in the social conditions under which individuals compose them.

The idea that social phenomena have both objective and subjective dimensions was central to how Thomas and Znaniecki conceptualized The Polish Peasant. The dichotomy is based on the premise that the world consists of objects which are perceived by subjects to exist as entities unto their own. The division produces questions about how subjects relate to objects. By this construction Thomas and Znaniecki intended to give coequal weight to an interplay between individual attitudes and objective cultural values as a means by which to understand social life.

The objective and subjective are parallel constructions to Thomas and Znaniecki's thoughts about, respectively, 'value' and 'attitude'. A social value is 'any object which has a meaning to a member of a social group so that it may become an object of activity to that member.' ${ }^{3}$ An attitude is 'a process of individual consciousness which determines real or possible activity of the

\footnotetext{
1 Drori et al. (2003).

${ }^{2}$ Meyer (1986): 199.

${ }^{3}$ Madge (1962): 66 (emphasis added).
} 
individual in the social world.' ${ }^{4}$ For Thomas and Znaniecki, social change was understood as the "product of continual interaction between individual consciousness and objective social reality. ${ }^{5}$

Causal explanation was to be found not in mechanistic notions and measurement of single-variable effects, but in the relation between objective factors and subjective dispositions ${ }^{6}$. This profound idea, conjoined with the imperative that objective-subjective interplay is located in time and place, encapsulates how the Chicago School thought about theory and theorizing. The influence of external or objective factors upon human conduct 'assumes importance only to the extent that they are subjectively experienced [...] it is the task of the analyst to try to show how subjective predispositions, or attitudes, molded by experience, determine the response of individuals to the objective factors that impinge upon them.. ${ }^{7}$ As Thomas and Znaniecki put it, sociology, in order for it to be robust, must focus on the process of becoming.

For Thomas and Znaniecki, the objective and subjective sides of social life are treated as both interactive and separable. Values and attitudes interact to constitute social life, but values and attitudes are distinct from each other. They can, in principle, be studied independently. Here, however, we have a hybridization of the construct. Objective and subjective are one form. The $\mathrm{CV}$ is at once subjectively constituted - an expression of what one has done - and objectively reflective of social conditions. They are not separable but are, rather, coterminous. In conterminal language, we are studying 'what individuals say regarding what society proclaims' about change in universities. Conversely, we examine 'what society says individuals are to say' about their careers.

Ontologically, the objective and the subjective are 'situated'. They are not static but rather dynamic properties of social reality. In informal terms they convey flux and movement. More formally they encompass process: there is temporality that transpires in a context, setting, or milieu. Time and place are the social dimensions taken by Thomas and Znaniecki, and other Chicago sociologists of the period, to be central to the study of social process which, by turn, accesses social and personal change. To study becoming - the core of social and personal change - the analyst must inquire into the social and cultural contexts in which actors are situated. Use of the biological metaphor 'ecology' captures the idea espoused by Thomas and Znaniecki and the Chicago School in which individuals adapt to change that they experience in their environment, which in turn is re-shaped by people's behaviour. Thomas and Znaniecki's brilliance in the Polish Peasant is demonstrated by revealing 'how the complexities of the social environment worked themselves out in individ-

\footnotetext{
4 Thomas, Znaniecki (1918-20), vol. 1: 22.

5 Bulmer (1984): 55.

6 Bulmer (1984); Janowitz (1966).

7 Coser (1971): 513.
} 
ual lives and then rebounded through the individuals to reshape the environment and its institutions. ${ }^{8}$

CVs locate people in time and place. People are situated in particular places (the universities in which they work) and in particular times (the professional age cohorts of which they are a part). The curriculum vitae as 'life document' lends itself as a prime means by which to examine the interplay between social and personal change as revealed by objective and subjective realities.

\section{EMPIRICAL MATERIALS}

The National Research Council (NRC) in the United States has conducted assessments of the country's graduate programmes. ${ }^{9}$ Ninety-five graduate programmes in the field of sociology have been evaluated..$^{10}$ Among the measures, the 'scholarly quality of program faculty' is the broadest or most over-arching. Programmes may be ranked using the measure. Burris has argued that most programmes, departments, and universities change little in rank over time. ${ }^{11}$ The present selection of ranked programmes is thus relatively stable in time.

Ten programmes, and not some other number, are used to constitute tiers because they capture sufficient variation at three intervals along a scale from 1 to 95 . Ten programmes ranked at the top, middle, and bottom of the NRC ranking are used in the analyses in order to examine organizational variation in publication patterns. While the programmes included in the sample are doctoral-granting departments, the departments and respective institutions run a considerable gamut, from Harvard and Stanford to Mississippi State and Kent State.

To examine patterns of publication, the curriculum vitae of the members of the 30 departments were downloaded from the internet. For 29 of the programmes, the CVs were downloaded June 8-10, 2015. For the one remaining programme, the CVs (nine in total) were downloaded on 27 June 2017 upon their becoming available on the Internet.

CVs are of tenure-line faculty (i.e. those listed as assistant, associate, or full professor). Of the 291 tenure-line faculty in the top ten sociology programmes, 247 (85.0\%) CVs were available online. Of the 208 tenure-line faculty in the middle ten sociology programmes, $180(87.0 \%) \mathrm{CVs}$ were available online. Of the 140 tenure-line faculty in the bottom ten programmes, $112(80.0 \%) \mathrm{CVs}$ were available online.

The resulting total of $539 \mathrm{CVs}$ were coded for the faculty member's number of peer-reviewed journal articles. The count of peer-reviewed journal

\footnotetext{
${ }^{8}$ Abbott (1999): 208.

${ }_{9}^{9}$ Discussion of methods for the present work relies on Hermanowicz, Clayton (2018).

${ }^{10}$ Goldberger, Maher, Flattau (1995).

${ }^{11}$ Burris (2004).
} 
articles excludes book chapters, book reviews, reprinted articles, replies, responses, commentaries, newsletter articles, essays, reports, conference presentations, and articles under review. Peer-reviewed journal articles are used as a measure of publication because the field, particularly in the U.S. context from which the data come, configures this genre centrally for the purposes of tenure and promotions. Other genres of publication are important, but none are as widespread as articles.

To ascertain publication patterns by career phase, the sample was divided into three cohorts, corresponding roughly to early, middle, and late career phases, as indicated by the year in which the sociologists earned their Ph.D. in relation to the time at which the present data were harvested. Cohort I, corresponding to late career phases, includes sociology faculty members who earned their Ph.D. prior to 1990. Cohort II, corresponding to mid-career phases, includes sociology faculty members who earned their Ph.D. between 1990 and 2005. Cohort III, corresponding to early career phases, includes sociology faculty members who earned their Ph.D. after 2005.

In addition, select data are computed using the Social Sciences Citation Index. Data from the Index are used to generate trends in publishing outlets over time. The journals listed in the Index are those that appear on the aforementioned CVs. Trends in the CVs are thus partly accountable by trends evinced in the Index.

\section{CHANGE IN ACADEMIC CAREERS}

I confine an empirical discussion to two important career domains: journal outlets for publication and publication productivity norms across tiers of work and cohorts of academics.

\section{Journal outlets}

Table 1 records the number of journals in the field of sociology in fifteen-year intervals between the year 1970 and $2015 .^{12}$ Based on the Social Sciences Citation Index, 78 sociology journals existed in 1970. In 2015, there were 142, an average increase of 1 per cent, or 1.5 journals, in each of the forty-five years covering the period. The upward pattern in journal number is not unique to the field of sociology. It is a general pattern observable in a large number of academic and professional fields.

Table 1 also lists the number of journals over time in selected fields that are arguably cognate to sociology. The list is but a sampling, and thus underestimates production volume by the people who call themselves sociologists.

${ }^{12}$ My consideration of journal outlets for publication is drawn from Hermanowicz (2016a). 
Table 1

Number of journals in sociology and selected cognate fields, 1970-2015

\begin{tabular}{|c|c|c|c|c|}
\hline Field & 1970 & 1985 & 2000 & 2015 \\
\hline Sociology & 78 & 83 & 96 & 142 \\
\hline Education & 103 & 114 & 96 & 231 \\
\hline Criminology & 18 & 22 & 20 & 58 \\
\hline Demography & 11 & 18 & 16 & 26 \\
\hline Urban Studies & 13 & 25 & 29 & 39 \\
\hline Women's Studies & - & 7 & 25 & 41 \\
\hline Communication & 11 & 24 & 43 & 78 \\
\hline Gerontology & 7 & 10 & 23 & 32 \\
\hline $\begin{array}{l}\text { Environmental } \\
\text { Studies }\end{array}$ & 15 & 34 & 47 & 103 \\
\hline Cultural Studies & - & - & - & 38 \\
\hline Family Studies & - & 23 & 31 & 42 \\
\hline Total & 256 & 360 & 426 & 830 \\
\hline
\end{tabular}

Sources: Institute for Scientific Information (1979) and (1987). Social Sciences Citation Index. Philadelphia: Institute for Scientific Information; and, Social Sciences Citation Index, 2000 and 2015 , Thompson Reuters, <http://ip-science.thompsonreuters.com>. Table originally published in Hermanowicz (2016a).

Using this sampling for illustration, there were a total of 256 journals in sociology and selected cognate fields in 1970 . The number steadily increased, such that by the year 2015 there were 830 , an increase, albeit an undercount, of 324 per cent. Put differently, by a conservative measure, an average of nearly 13 new journals in which sociologists were able to publish their work were available in each of the forty-five years between 1970 and 2015. The pattern in the number of journals over time conveys an unmistakable intensification of the research role.

\section{Publication productivity norms}

Members of the sample generally do not stop publishing: the act of publication has become a consistent part of the professorial role across the broad spectrum of programmes. ${ }^{13}$ Examining Table 2, both the mean and median number of publications in each of the cohorts increases as cohorts age.

${ }^{13}$ Points bearing on publication norms are derived from Hermanowicz, Clayton (2018). 
Table 2

Peer reviewed articles, by program tier and cohort

\begin{tabular}{|c|c|c|c|c|}
\hline & Cohort I & Cohort II & Cohort III & \multirow{2}{*}{ Total } \\
\hline Program Tier & Ph.D. Pre-1990 & Ph.D. 1990-2005 & Ph.D. Post-2005 & \\
\hline \multicolumn{5}{|l|}{ Top 10} \\
\hline $\mathrm{N}$ & 95 & 97 & 53 & 245 \\
\hline Minimum & 3 & 3 & 1 & 1 \\
\hline Maximum & 181 & 91 & 73 & 181 \\
\hline Median & 33.0 & 18.0 & 9.0 & 20.0 \\
\hline Mean & 44.2 & 22.0 & 11.4 & 29.0 \\
\hline \multicolumn{5}{|l|}{ Middle 10} \\
\hline $\mathrm{N}$ & 58 & 68 & 53 & 179 \\
\hline Minimum & 5 & 1 & 0 & 0 \\
\hline Maximum & 186 & 43 & 42 & 176 \\
\hline Median & 30.0 & 17.0 & 7.0 & 16.0 \\
\hline Mean & 39.3 & 17.0 & 10.4 & 22.2 \\
\hline \multicolumn{5}{|l|}{ Bottom 10} \\
\hline $\mathrm{N}$ & 18 & 48 & 44 & 110 \\
\hline Minimum & 3 & 5 & 0 & 0 \\
\hline Maximum & 114 & 85 & 29 & 114 \\
\hline Median & 27.0 & 18.0 & 5.0 & 13.0 \\
\hline Mean & 34.0 & 20.4 & 7.1 & 17.3 \\
\hline
\end{tabular}

Source: adapted from Hermanowicz (2016a).

Consider the mean number of publications for cohort I. For the top tier programmes, the number is 44.2 , for the middle tier programmes, 39.3, and for the bottom tier programmes, 34.0. For cohort II, the mean number of article publications is 22.0 at the top, 17.0 in the middle, and, particularly noteworthy, 20.4 at the bottom. For cohort III, the mean number of article publications is 11.4 at the top, 10.4 in the middle and 7.1 at the bottom. The tiers are sharply divided in reputation, yet such organizational division belies actual production of research work. Table 2 shows that, across cohorts and program tiers, publication has become a diffused, stable part of the academic role.

Publication patterns potentially vary in significant ways by important career thresholds: how much incumbents have published by the time of their first academic job, by the time of tenure and promotion to associate professor, and by the time of promotion to full professor. Organizational differences in 
prestige suggest that it would require more in terms of publication at each of these thresholds as prestige in academic departments increases.

Table 3

Article performance, by program tier and career stage

\begin{tabular}{|c|c|c|c|}
\hline & Cohort I & Cohort II & Cohort III \\
\hline & Ph.D. Pre-1990 & Ph.D. 1990-2005 & Ph.D. Post-2005 \\
\hline \multicolumn{4}{|l|}{ Top 10} \\
\hline $\begin{array}{l}\text { Average \# of articles } \\
\text { at first job }{ }^{\alpha}\end{array}$ & $\begin{array}{r}2.3 \\
(\mathrm{~N}=87)\end{array}$ & $\begin{array}{r}3.1 \\
(\mathrm{~N}=93)\end{array}$ & $\begin{array}{r}4.2 \\
(\mathrm{~N}=52)\end{array}$ \\
\hline $\begin{array}{l}\text { Average \# of articles } \\
\text { at tenure }\end{array}$ & $\begin{array}{r}9.3 \\
(\mathrm{~N}=68)\end{array}$ & $\begin{array}{r}10.0 \\
(\mathrm{~N}=83)\end{array}$ & $\begin{array}{r}14.3 \\
(\mathrm{~N}=12)\end{array}$ \\
\hline $\begin{array}{l}\text { Average \# of articles } \\
\text { at full professor }\end{array}$ & $\begin{array}{r}16.0 \\
(\mathrm{~N}=74)\end{array}$ & $\begin{array}{r}18.2 \\
(\mathrm{~N}=48)\end{array}$ & $\begin{array}{r}9.0 \\
(\mathrm{~N}=1)\end{array}$ \\
\hline \multicolumn{4}{|l|}{ Middle 10} \\
\hline $\begin{array}{l}\text { Average \# of articles } \\
\text { at first job }\end{array}$ & $\begin{array}{r}2.2 \\
(\mathrm{~N}=51)\end{array}$ & $\begin{array}{r}2.9 \\
(\mathrm{~N}=61)\end{array}$ & $\begin{array}{r}3.4 \\
(\mathrm{~N}=53)\end{array}$ \\
\hline $\begin{array}{l}\text { Average \# of articles } \\
\text { at tenure }\end{array}$ & $\begin{array}{r}10.0 \\
(\mathrm{~N}=41)\end{array}$ & $\begin{array}{r}10.2 \\
(\mathrm{~N}=50)\end{array}$ & $\begin{array}{r}14.8 \\
(\mathrm{~N}=14)\end{array}$ \\
\hline $\begin{array}{l}\text { Average \# of articles } \\
\text { at full professor }\end{array}$ & $\begin{array}{r}18.5 \\
(\mathrm{~N}=40)\end{array}$ & $\begin{array}{r}18.3 \\
(\mathrm{~N}=16)\end{array}$ & $\begin{array}{r}14.0 \\
(\mathrm{~N}=2)\end{array}$ \\
\hline \multicolumn{4}{|l|}{ Bottom 10} \\
\hline $\begin{array}{l}\text { Average \# of articles } \\
\text { at first job }\end{array}$ & $\begin{array}{r}1.7 \\
(\mathrm{~N}=16)\end{array}$ & $\begin{array}{r}2.3 \\
(\mathrm{~N}=46)\end{array}$ & $\begin{array}{r}3.0 \\
(\mathrm{~N}=41)\end{array}$ \\
\hline $\begin{array}{l}\text { Average \# of articles } \\
\text { at tenure }\end{array}$ & $\begin{array}{r}10.0 \\
(\mathrm{~N}=14)\end{array}$ & $\begin{array}{r}11.0 \\
(\mathrm{~N}=45)\end{array}$ & $\begin{array}{r}13.0 \\
(\mathrm{~N}=5)\end{array}$ \\
\hline $\begin{array}{l}\text { Average \# of articles } \\
\text { at full professor }\end{array}$ & $\begin{array}{r}17.0 \\
(\mathrm{~N}=10)\end{array}$ & $\begin{array}{r}24.2 \\
(\mathrm{~N}=12)\end{array}$ & $\begin{array}{r}- \\
(\mathrm{N}=0)\end{array}$ \\
\hline
\end{tabular}

${ }^{a}$ Coded as the first time incumbents had the title 'assistant professor'.

Source: Hermanowicz, Clayton (2018).

Table 3 paints a quite different picture than we might imagine. The table presents the average number of peer-reviewed articles that sociologists had published, by cohort and by program tier, by the time they gained their first academic job, tenure, and promotion to full professor. Let us first consider patterns across tiers, beginning with cohort I. For academics presently employed in the top 10 programmes, the average number of articles at their first job was 2.3. For the middle 10 programmes it was 2.2 . And for the bottom 10 programmes, 1.7 . 
The average number of articles by the time of tenure was, respectively, 9.3, 10.0, and 10.0. For full professor, the average number of articles, respectively across the cohorts, was 16.0,18.5, and 17.0. At all three career markers, people in the middle tier performed either equivalently or outperformed those at the top. People in cohort I in the bottom tier were not far behind.

In cohort II the patterns are roughly similar. Looking at cohort II, sociologists presently employed in the top tier had published an average of 3.1 articles at the time of their first academic job, in the middle tier, 2.9, and in the bottom tier, 2.3. For tenure, the figures are, respectively, 10.0, 10.2, and 11.0. Sociologists in the bottom tier actually published an average of one more article to gain tenure than their counterparts in the top tier programs.

For full professor, the averages are, respectively, 18.2, 18.3, and 24.2. This is to say that sociologists in the middle tier out-performed those in the top tier in two of the measures (articles at tenure and full professor) and measured equally in the third (articles at first job). In two of the measures (articles at tenure and at full professor), sociologists in the bottom tier actually out-performed their peers at the top. Similar patterns are detectable in cohort III, but the sample sizes are smaller, given that many have not yet achieved tenure or full professor. It is simply worth noting that at the time of their first job, sociologists presently employed in the top tier had published an average of 4.2 articles, in the middle, 3.4, and in the bottom, 3.0 - remarkably similar performances.

Now let us consider differences across cohorts beginning with the top tier. The predominant patterns convey that as time advances it becomes more difficult to meet the given thresholds. For the average number of articles at the first job, cohort I had published 2.3, cohort II, 3.1, and cohort III, 4.2. For the average number of articles at tenure, cohort I had published 9.3, cohort II, 10.0, and cohort III, 14.3. The same overall patterns hold for those employed in the middle and in the bottom tiers. Collectively, the trends suggest not only that it becomes more difficult to meet key career thresholds over time, but that these effects are diffused across the tiers of academic employment. Norms governing academic careers evince social change. The patterns illustrate a diffusion and intensification of the research role across the contexts of work and cohorts of academics.

\section{DISCUSSION}

Where once research was concentrated in a subset of institutions in the U.S., it is increasingly institutionalized in a greater variety of institutions. And where once research productivity concentrated in early career phases, particularly in institutions outside of the elite sector in the U.S., it is increasingly normative throughout advanced stages of academic careers.

The diffusion of the research role is both a national phenomenon in the U.S. system of higher education and a global development reaching institu- 
tions in varieties of national systems throughout the world. Globally, the academic profession, in the aggregate, remains a teaching profession. But this is changing: the role matrix of academic careers in national systems is increasingly absorbing a research component.

A present concern in the literature on the international professoriate encompasses the idea of convergence. ${ }^{14}$ This idea holds that where once the professoriate was highly differentiated by country, it is becoming increasingly isomorphic, insofar as its basic form and accompanying problems are concerned..$^{15}$ Convergence is an expression of institutional theory. ${ }^{16}$

'Universities and colleges, together with their disciplinary fields and academic roles, are defined, measured, and instantiated in essentially every country in explicitly global terms. ${ }^{17}$ Institutional theory predicts isomorphic change in education organizations and in the professoriate in ways that mimic the practices found in the most successful (e.g. highly-ranked) universities and related national systems. ${ }^{18}$ Research under the rubric of institutional theory has generally focused on rudimentary elements such as enrolment, university structure, and curriculum. The institutionalization of the research role globally may be understood herein as a new, more recent component of isomorphic change.

An ascension of the research role may not be in and of itself problematic. We may treat as problematic, however, the sources and consequences of the rise of research. The sources and consequences of an ascendance of research are themselves becoming isomorphic: they transcend national boundaries and are symptomatic of social forces affecting national systems in a more or less blanket manner.

The sources of social change that precipitate a rise in research are located in the ascendance of the market. ${ }^{19}$ In particular, the university as a worldwide institution has taken on the characteristics of private enterprise. Slaughter, Leslie, and Rhoades refer to this transformation as encompassing 'academic capitalism' - market and market-like behaviours in universities and among faculty. ${ }^{20}$ Behaviour in academic-capitalist mode includes institutional and faculty competition for monies, giving way to a 'corporatization of higher education'. ${ }^{21}$

Academic-capitalist behaviour, both institutional and individual, has ascended in prominence under the socio-political conditions of neoliberalism, where neoliberalism can be defined as a theory of political economic practices that proposes that human well-being can best be advanced by liberating individual entrepreneurial freedoms and skills within an institutional frame-

\footnotetext{
${ }^{14}$ Hermanowicz (2018).

15 Shin, Kehm (2013); Teichler (2014).

${ }_{16}$ Meyer, Rowan (1977); see also Krücken, Drori (2009).

17 Meyer et al. (2007): 188.

18 Bentley, Kyvik (2011).

19 For related discussion, see Hermanowicz (2016b).

20 Slaughter, Leslie (1997); Slaughter, Rhoades (2001).

21 Slaughter, Leslie (2001).
} 
work characterized by strong private property rights, free markets and free trade [...]. ${ }^{22}$ As Slaughter states, 'a neoliberal state shifts higher education from a public good knowledge/learning regime to [...] an academic capitalist knowledge/ learning regime'. ${ }^{23}$ The privatization of higher education is an outcome of neoliberal ideology.

A broad and increasingly pervasive array of institutional and individual behaviours are indicative of these patterns: the search and competition for external grants and contracts, endowment funds, university-industry partnerships, spin-off companies, student tuition and fees, patenting and licensing agreements, and the sale of products and services enshrined in logos, sports paraphernalia, food facilities, and bookstores. ${ }^{24}$ The search and competition have ancillary effects, as institutions spend monies in order to attract economic returns: in athletics programs, lavish sports, recreational, housing, and dining facilities; health centres and transit systems; study abroad programs in numerous locations; technology, and the like.

These changes became forceful especially in the 1980s and were reinforced by influential political leaders such as Ronald Reagan and Margaret Thatcher. A philosophy of neoliberalism spread and intensified.

...[F]rom the 1980s onwards, traditional European university structures have been facing significant changes. The starting point was changes in the British university system...that quickly spread to the Scandinavian countries and the Netherlands...Later we find reforms in France...Italy...Germany... and Eastern European countries...In recent years, research has shown a move in nearly all European countries toward... [New Public Management]. ${ }^{25}$

Whereas Clark in 1983 emphasized the beliefs of 'liberty' and 'loyalty' as central to academic organization, ${ }^{26}$ Brennan suggests that these values have been replaced by such notions as 'competitiveness' and 'entrepreneurship'. ${ }^{27}$

In an academic-capitalist age, economic returns coupled with prestige are the central objects over which institutions and faculty members compete. The competition is fuelled to a large extent by public-to-private shifts in revenue streams, but not exclusively so. It is fortified by the crystallization of rankings, such as the U.S. News and World Report ranking of institutions and programs, whose origination in 1983 coincided with the onset of marketization and corporatist developments in U.S. higher education. Rankings of universities are themselves now global, pointing to a common ground that sustains an increasingly institutional, world-wide enterprise, wherein prestige operates as the main currency to undergird institutional functioning. ${ }^{28}$ The institutionalization of the research role in universities world-wide serves their competitive quests for money.

\footnotetext{
22 Harvey (2005): 2.

23 Slaughter (2011): 267.

${ }_{24}$ Slaughter, Leslie (2001).

${ }^{25}$ Hüther, Krücken (2016): 56.

${ }_{26}$ Clark (1983): 247-251.

27 Brennan (2010): 234.

28 Shin, Toutkoushian, Teichler (2011).
} 
What are the consequences of this massive social change in higher education? The consequences are likely to be numerous and varied. Some have argued that neoliberalism is 'the most dangerous ideology of the current historical moment' because civil discourse gives way 'to the language of commercialization, privatization, and deregulation'. Citizenship amounts to a privatized affair among self-interested individuals. As a result, such observers have reasoned, 'the meaning and purpose of higher education' is thrown into question. ${ }^{29}$

Priorities in universities are undergoing a dramatic shift: from the intellectual to the market, from knowledge to money. Sociologically, change in priority means that new and different behaviour is valued, recognized, and sanctioned. If academic culture is differently conditioned, the ground is likely to shift with regard to experience, attitude, and the interpretation of work.

I focus on personal change; that is, on specific social-psychological consequences, since such a concern seeks to address, in ways parallel to Thomas and Znaniecki's formulation of the study of society, how changes in the social environment are worked-out in individual lives and then expressed in behaviour that re-generates institutions. In ways akin to the Polish peasant of Chicago, we inquire into how the new 'society' of higher education affects the self, so as to evince the dialogical ties between the social and personal orders.

\section{TOWARD A THEORY OF KNOWLEDGE PRODUCTION}

What is academic work becoming? What are universities becoming? I contend that the changed infrastructure of knowledge in universities limits the actual knowledge that can be produced. The sorts of knowledge that young professors seek to produce to keep their jobs, the sorts of knowledge that professors seek to 'keep up the numbers', are contemporary manifestations of how a changed work infrastructure constrains the production of knowledge worth producing.

Academic capitalism has given way to a regimen of quantification in faculty work, an obsession with measuring, comparing, and sanctioning performance, in many facets of academic roles. The way in which a faculty reward system operates is undergirded by the rise of the institutional 'audit'. Universities now require faculty members to account for themselves by engaging in rituals of verification - documenting and recording their activities on an annual basis. ${ }^{30}$ Administrators are charged with generating evaluations of how individuals and units are performing. ${ }^{31}$ This can create the sense that administrators govern faculty rather than govern with them. ${ }^{32}$

\footnotetext{
${ }^{29}$ Giroux (2002): 425.

30 Power (1997).

31 Miller, O’Leary (1987).

32 Tuchman (2009).
} 
In addition, these practices encourage what has been called an 'accountability regime', wherein academic work gets reconfigured in a metric reality. ${ }^{33}$ Professors become auditable commodities, and the system comprises a 'new managerialism' that undercuts faculty authority by implementing change from the top down. ${ }^{34}$ The practices create a new standard of economic rationality in university decision-making. ${ }^{35}$ 'Rather than universities being subordinated to the production and transmittal of knowledge, knowledge is now subordinated to the needs of universities for profit and recognition. ${ }^{36}$

What is more, it is not only that knowledge is de-centered and displaced for money, but also that interest in and seriousness with knowledge is weakened in a culture of academic capitalism. This minimizes intellectual behaviour in universities. Commensuration, the process of attributing meaning to measurement, 'changes the form and circulation of information and how people attend to it'. ${ }^{37}$ For instance, administrators might note that a professor published 100, 200, or 400 articles, but not explain why the articles mattered. ${ }^{38}$ Similarly, they elevate student evaluations of teaching, like citation counts and impact factors, among numerous other metrics, even if they do not know what they mean, or how to explain the difference between 3.8 and 4.2. The quest to be number 1 , or in the top 10 , or 25 , or 50 - instantiations of market behaviour - can seem largely devoid of meaning; that is, unrelated to ideas. But a lack of engagement with ideas under academic capitalism is found not only in administrators who oversee the regime but also in faculty members whose responsive behaviour helps to sustain it.

The new academic economy exacts motivational behaviour for publication. Increase in the number of journals, for example (Table 1), is a pattern accommodative to neoliberalism. An emphasis on research maximizes a specific type of faculty member: ritualists. In Merton's terms, ritualism is an individual mode of adaptation. ${ }^{39}$ Here it is behaviour adaptive to academic capitalism. As ritualists, people fail to believe in the goals of a system, but continue to engage in means geared towards satisfying those goals. Throughout many sectors of higher education, the penalties of not publishing are now perceived as high.

Ritualism is indicative of a more substantial consequence of contemporary change in higher education around the globe: alienation. Publishing articles ritualistically to satisfy the market interests of their employers, many professors have become like factory workers producing widgets, automatons on an assembly line. Paradox abounds in the ascendance of the research role: a decline in the quality of publication, a decrease in creative work, a shrinkage in the time spent actually thinking. Thought fosters higher quality work. But under academic capitalism, like capitalism broadly, time is money. Thus time

\footnotetext{
${ }^{33}$ Hopwood (1987); Tuchman (2009).

34 Tuchman (2009): 11.

35 Geiger (2004).

36 Tuchman (2009): 11.

37 Espeland, Sauder (2007): 333.

38 Tuchmann (2010).

${ }^{39}$ Merton [1957] 1968).
} 
is scuttled for satisfying annual publication quotas - a rush to publish. Ritualistic publication seeks to satisfy commensurate metrics, without necessarily making worthwhile contributions to knowledge.

How do alienated professors go about their work? To illustrate, a former editor of a major American sociology journal offered the following confession.

When I started as editor, I worried that the biggest challenge would be...: How will I choose from among all the great submissions?...That worry was based on my sense that a high percentage of submissions would be - or could, with modest revision, become - publishable. In fact, I consistently had exactly the opposite problem. For each of the...issues I published, I struggled to find four high-quality publishable manuscripts... Most papers that I read had one or both of two basic problems...[First,] a large percentage...had fundamental research design flaws...Second...most papers simply lacked a soul - a compelling and well-articulated reason to exist...most papers failed to make a good case for why they were necessary...I think there are two related explanations for why the vast majority of...submissions... were simply not all that great...First, junior scholars are under far too much pressure to quickly publish lots and lots of papers. The problem is that it takes time and thought and trial and error to generate a really compelling research question and to deeply understand how to articulate the importance of that question. Then, it takes more time and thought and trial and error to come to a really convincing answer to that question, to fully develop the argument or story, and to write a manuscript that does justice to the value of the research. Unfortunately, junior scholars do not have enough time or enough room to think...Graduate students must publish frequently - while still in graduate school - to compete for fellowships and professional jobs. Assistant professors must publish early and often to get tenure; associate professors must do the same to "make full." In each case, the pressure is to work quickly and efficiently. They have to get papers out for review as soon as possible, even if they haven't had the time to think them through or sharpen their argument or evidence. Quantity matters most, not quality. The incentive is to publish a dozen "just OK" papers rather than to publish four or five well-developed and higher quality papers. The collective result...: a mass of underdeveloped papers...These are papers that exist for the sake of being papers because the author is under pressure to write lots of papers...There simply has to be a better way to run a profession..$^{40}$

Increasingly, audit rituals and accountability structures incentivize publication regardless of institutional location, career stage, or national system. In these ways, academia is thought to be 'accelerating' wherein the very structure of time has changed in response to publication demands. ${ }^{41}$ Calls to actually 'slow down professors' capture the pitch of neoliberalism. ${ }^{42}$

In this wedding of views, Thomas and Znaniecki meet Marx. Following Marx, the forms of alienation arising in academic work are postulated as four-fold: alienation from the objects academics produce (their articles, their books), from the process of production (thinking and writing), from themselves (those who work for someone or something other than authentic intellectual interests), and from each other (colleagues who, defying the original logic of departments and colleges, rarely converse or socialize with one another, let alone read one another's work) ${ }^{43}$ In this new infrastructure of knowledge production, professors do not work to express themselves, to develop their interests, to gain intrinsic sat-

\footnotetext{
${ }^{40}$ Warren (2016); original emphasis.

${ }^{41}$ Vostal (2016).

${ }^{42}$ Berg, Seeber (2016).

${ }^{43}$ Marx (1964).
} 
isfaction, or to make significant contributions. Rather, work is essentially forced and, in work, they are subjected to the demands and discipline of others. One's publications become alien objects, quickly shelved and un-reread upon receipt, for one has long since moved on to the next.

Academic labour is increasingly performed on behalf of performance scores: scores in teaching, in research, in service activities, in everything, for now everything, like having lunch or going to a museum, avails itself to be 'rated'. (At least one department on the planet introduced points professors can earn for making 'constructive' contributions at faculty meetings.) Alternatively, academics must explicitly reject and develop defences against such goals despite mounting pressure around them. This is perhaps easier in some types of institutions than in others. ${ }^{44}$ To actually have to work, in attitude and deed, against a set of forces is its own evidence of institutional change - and demonstrative of the Thomas theorem: If a situation is perceived as real, it has real consequences..$^{45}$

Studying immigrants, Thomas and Znaniecki understood their work as a type of approach they would like to see applied to other problems of social becoming. ${ }^{46} \mathrm{CVs}$, we may conclude, indicate social and personal change, revelations of new orders - and a set of social and personal problems. The problems, inhering in society's archetypal profession, are not short on irony. The intensification of research limits knowledge. The diffusion of research activity weakens discovery. We are becoming poorer intellectually for all the "knowledge' we are creating. One hundred years following the study of peasants, in this study of professors, the modern curriculum vitae offers a window on what knowledge is becoming, expressed in the dialogic relationship between present-day institutions and individuals.

Joseph C. Hermanowicz

University of Georgia, Athens, USA

jch1@uga.edu

https://orcid.org/0000-0001-5155-4941

Abbott, A. (1999). Department and Discipline: Chicago Sociology at One Hundred. Chicago: University of Chicago Press.

Bentley, P.J., Kyvik, S. (2012). Academic work from a comparative perspective: a survey of faculty working time across 13 countries. Higher Education 63: 529-547.

Berg, M., Seeber, B.K. (2016). The Slow Professor: Challenging the Culture of Speed in the Academy. Toronto: University of Toronto Press.

Brennan, J. (2010). Burton Clark's The Higher Education System: Academic Organization in Cross-National Perspective. London Review of Education 8(3): 229-237.

Bulmer, M. (1984). The Chicago School of Sociology: Institutionalization, Diversity, and the Rise of Sociological Research. Chicago: University of Chicago Press.

Burris, V. (2004). The academic caste system: prestige hierarchies in Ph.D. exchange networks. American Sociological Review 69(2): 239-264.

\footnotetext{
44 Hermanowicz (2011).

45 Thomas (1923).

${ }^{46}$ Madge (1963).
} 
Clark, B.R. (1983). The Higher Education System: Academic Organization in Cross-National Perspective. Berkeley: University of California Press.

Coser, L.A. (1971). W.I. Thomas and Florian Znaniecki, [in:] L.A. Coser, Masters of Sociological Thought. New York: Harcourt Brace Jovanovich: 511-559.

Drori, Gillis, S., Meyer, J.W., Ramirez, F., Schafer, E. (2003). Science in the Modern World Polity: Institutionalization and Globalization. Stanford: Stanford University Press.

Espeland, W.N., Sauder, M. (2007). Rankings and reactivity: how public measures recreate social worlds. American Journal of Sociology 113(1): 1-40.

Geiger, R.L. (2004). Knowledge and Money: Research Universities and the Paradox of the Marketplace. Stanford: Stanford University Press.

Giroux, H.A. (2002). Neoliberalism, corporate culture, and the promise of higher education: the university as a democratic sphere. Harvard Educational Review 72(4): 425-463.

Goldberger, M.L., Maher, B.A., Flattau, P.E. (eds.) (1995). Research-Doctorate Programs in the United States: Continuity and Change. Washington, D.C.: National Academy Press.

Harvey, D. (2005). A Brief History of Neoliberalism. Oxford: Oxford University Press.

Hermanowicz, J.C. (2011). Anomie in the American academic profession, [in:] J.C. Hermanowicz (ed.), The American Academic Profession: Transformation in Contemporary Higher Education. Baltimore: Johns Hopkins University Press: 216-237.

Hermanowicz, J.C. (2016a). The proliferation of publishing: economic rationality and ritualized productivity in a neoliberal era. American Sociologist 47(2): 174-191.

Hermanowicz, J.C. (2016b). Universities, academic careers, and the valorization of 'shiny things', [in:] E.P. Berman, C. Paradise (eds.), Research in the Sociology of Organizations 43: 303-328.

Hermanowicz, J.C. (2018). The professoriate in international perspective, [in:] M.B. Paulson (ed.), Higher Education: Handbook of Theory and Research. Cham, Switzerland: Springer: 239-293.

Hermanowicz, J.C., Clayton, K.A. (2018). Contemporary academic publishing: democratization and differentiation in careers. Journal of Higher Education 89(6): 865-891.

Hopwood, A.G. (1987). The archeology of accounting systems. Accounting, Organizations and Society 12(3): 207-234.

Hüther, O., Krücken, G. (2016). Nested organizational fields: isomorphism and differentiation among European universities, [in:] E.P. Berman, C. Paradeise (eds.), Research in the Sociology of Organizations: The University Under Pressure. Bingley: Emerald: 53-83.

Janowitz, M. (1966). Introduction, [in:] M. Janowitz (ed.), W.I. Thomas: On Social Organization and Social Personality. Chicago: University of Chicago Press: vii-lviii.

Krücken, G., Drori, G.S. (2009). World Society: The Writing of John W. Meyer. Oxford: Oxford University Press.

Madge, J. (1962). The Origins of Scientific Sociology. New York: Free Press.

Marx, K. (1964). Early Writings. Translated and edited by T.B. Bottomore. New York: McGrawHill.

Merton, R.K. [1957] 1968). Social structure and anomie, [in:] R.K. Merton, Social Theory and Social Structure, New York: Free Press: 185-214.

Merton, R.K. (1973). The Sociology of Science: Theoretical and Empirical Investigations. Edited and with an Introduction by N.W. Storer. Chicago: University of Chicago Press: 267-278.

Meyer, J.W. (1986). The self and the life course: institutionalization and its effects, [in:] A.B. Sorensen, F.E. Weinert, L.R. Sherrod (eds.), Human Development and the Life Course: Multidisciplinary Perspectives. Hillsdale, NJ: Lawrence Erlbaum: 199-216.

Meyer, J.W., Rowan, B. (1977). Institutionalized organizations: Formal structure as myth and ceremony. American Journal of Sociology 83: 340-363.

Meyer, J.W., Ramirez, F.O., Frank, D.J., Schofer, E. (2007). Higher education as an institution, [in:] P. Gumport (ed.), Sociology of Higher Education: Contributions and Their Contexts. Baltimore: Johns Hopkins University Press: 187-221.

Miller, P., O'Leary, T. (1987). Accounting and the construction of the governable person. Accounting, Organizations and Society 12(3): 35-265.

Power, M. (1997). The Audit Society: Rituals of Verification. Oxford: Oxford University Press.

Shin, J.C., Kehm, B.M. (eds.) (2013). Institutionalization of World-Class University in Global Competition. Dordrecht: Springer. 
Shin, J.C., Toutkoushian, R.K., Teichler, U. (2011). University Rankings: Theoretical Basis, Methodology and Impacts on Global Higher Education. Dordrecht: Springer.

Slaughter, S. (2011). Academic freedom, professional autonomy, and the state, [in:] J.C. Hermanowicz (ed.), The American Academic Profession: Transformation in Higher Education. Baltimore: Johns Hopkins University Press: 241-273.

Slaughter, S., Leslie, L. (1997). Academic Capitalism: Politics, Policies, and the Entrepreneurial State. Baltimore: Johns Hopkins University Press.

Slaughter, S., Rhoades, G. (2004). Academic Capitalism and the New Economy: Markets, State, and Higher Education. Baltimore: Johns Hopkins University Press.

Teichler, U. (2014). On the move towards a new convergent design of higher education systems? [in:] J.C. Shin, U. Teichler (eds.), The Future of the Post-Massified University at the Crossroads. Dordrecht: Springer: 229-248.

Thomas, W.I. (1923). The Unadjusted Girl. Boston: Little, Brown.

Thomas, W.I., Znaniecki, F. [1918-20] 1958). The Polish Peasant in Europe and America. Vols. 1-5. New York: Dover.

Thompson-Reuters (2000). Social Sciences Citation Index. <http://ip-science.thompsonreuters. com>.

Thompson-Reuters (2015). Social Sciences Citation Index. <http://ip-science.thompsonreuters. com>.

Tuchman, G. (2009). Wannabe U: Inside the Corporate University. Chicago: University of Chicago Press.

Vostal, F. (2011). Accelerating Academia: The Changing Structure of Academic Time. Houndsmills, Basingstroke, UK: Palgrave Macmillan.

Warren, R. (2016). One Thing I Learned By Editing Sociology of Education. < https://thesocietypages.org/edsociety/2016/08/03/one-thing-i-learned-by-editing-sociology-of-education/> [Downloaded 26 April 2018].

\section{CHANGE - SOCIAL AND PERSONAL: \\ THOMAS AND ZNANIECKI'S THE POLISH PEASANT \\ FOR THE STUDY OF PRESENT-DAY CHANGE IN GLOBAL HIGHER EDUCATION}

Sum mary

The present work represents an extrapolation of W.I. Thomas and Florian Znaniecki's study, The Polish Peasant in Europe and America, on behalf of the development of sociological theory. The article focuses on careers and institutions in higher education. The curriculum vitae serves as the novel human document by which to investigate both social and personal change. Academic careers are studied by virtue of their objective and subjective dimensions. Objectively, the institution of education is revealed through the shifting expectations that govern work in academia in specific historical times (indicated by the cohort in which academics earned their Ph.D.s) and in specific socially bound places (indicated by the type of university in which academics work). Major social change in education is likely to spell personal change for the way in which people subjectively experience the contemporary academic career. The data come from U.S.-based academics; parallel transformational changes are observable globally. The global change discussed in the work centres on the diffusion and institutionalization of the research role. The sources and consequences of this change are problematic. Akin to Thomas and Znaniecki's larger analytic aims, patterns of change are used inductively to formulate theory: the paper culminates by postulating a theory of increasing tendencies in the way knowledge is produced in higher education institutions throughout the world.

Keywords: curriculum vitae; academic careers; transformational changes; knowledge production 
